\title{
European Trade, Colonialism, and Human Capital Accumulation in Senegal, Gambia and Western Mali, 1770-1900
}

\author{
Gabriele Cappelli and Joerg Baten
}

We trace the development of human capital in today's Senegal, Gambia, and Western Mali between 1770 and 1900. European trade, slavery, and early colonialism were linked to human capital formation, but this connection appears to have been heterogeneous. The contact with the Atlantic slave trade increased regional divergence, as the coast of Senegambia developed more quickly than inner areas. This pattern was affected by French early colonialism and by the reaction of different West African populations to the economic incentives provided by foreign demand for agricultural products. The peanut trade since the mid-nineteenth century further amplified regional economic inequalities.

\begin{abstract}
large amount of literature exists on the diverse effects of colonialism on development, but studies based on quantitative evidence are still in short supply. We assess the impact of exposure to European trade and early colonization on human capital in the regions of today's Senegal, Gambia and Western Mali between the late-eighteenth century and the eve of the twentieth century. Figure 1 maps the area that we study. We proxy human capital with an index of numeracy, which is arguably one of the core factors of economic development (Hanushek and Woessmann 2012; Baten 2016). With this approach, we estimate human capital trends between 1770 and 1900 and put forward a number of interpretations about their determinants.
\end{abstract}

The Journal of Economic History, Vol. 77, No. 3 (September 2017). (C) The Economic History Association. All rights reserved. doi: 10.1017/S0022050717000699

Gabriele Cappelli is Visiting Professor, Universitat Autònoma de Barcelona, Departament d'Economia i d'Història Econòmica (Edifici B), 08193 Bellaterra, Barcelona, Spain. E-mail: gabriele.cappelli@uab.cat. Joerg Baten is Professor of Economic History, University of Tuebingen, CEPR and CESifo, Melanchthonstraße 30,72074 Tuebingen, Germany. E-mail: joerg.baten@uni-tuebingen.de.

We would like to express our gratitude to William Collins and two anonymous referees for invaluable comments on the manuscript. The article has greatly benefitted from remarks provided by Ewout Frankema and Gareth Austin on early drafts. We would like to acknowledge the precious help provided by numerous research assistants, especially Bastien Buchwalter, Jorge Luis Fernández González, and Nicole Püschel. Finally, we would like to thank the participants of the Research Seminar at the Chair of Economic History of the University of Tuebingen, the 2014 ClioInfra Workshop at the University of Barcelona, and the EHES Conference 2015 in Pisa for their criticism and suggestions. Our work has been supported by the NWO ClioInfra Project and the German Science Foundation cluster SFB 1070. Cappelli also acknowledges the support of the Spanish Government through the project HAR2016-76814-C2-1-P (AEI/FEDER, UE). 


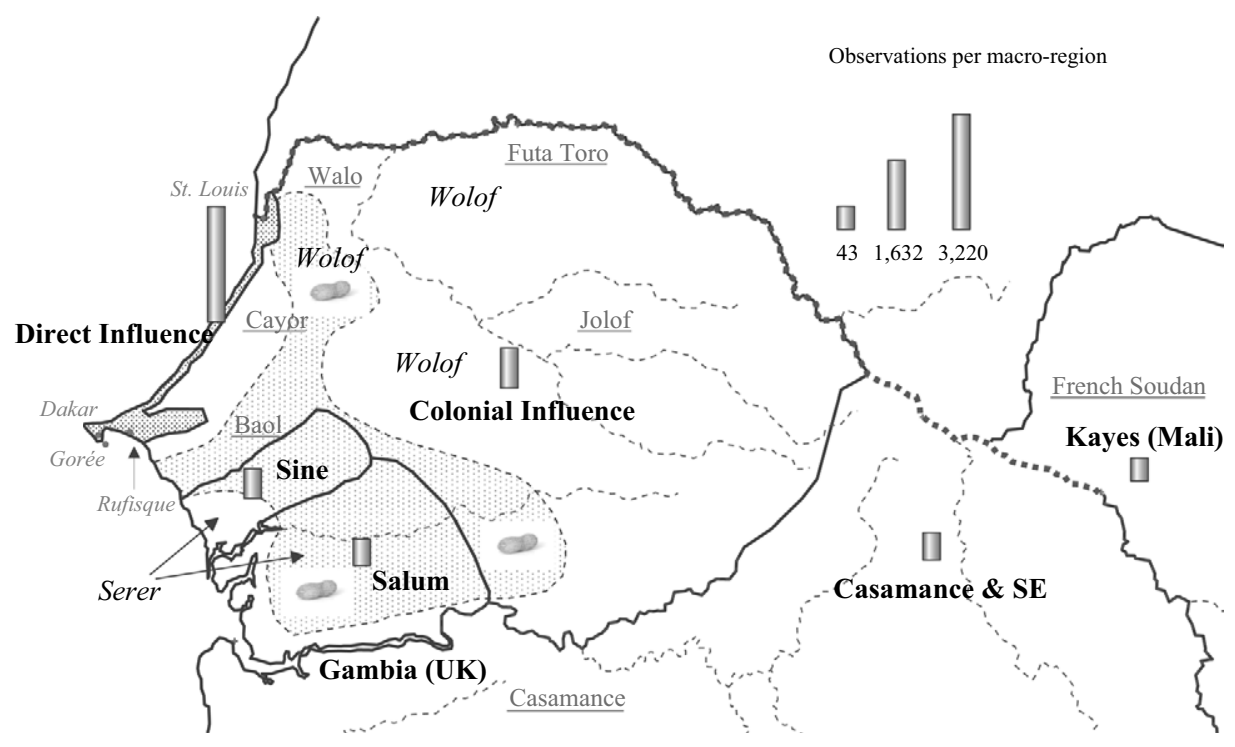

FIGURE 1

THE MAP SHOWS WESTERN SUDAN (SENEGAMBIA AND WESTERN MALI)

Notes: The bold, black lines identify the approximate borders of the macro-regions that we take into account in our econometric analysis of the correlates of numeracy. The area of Direct Influence includes the Four Communes along the coast of today's Senegal (St. Louis, Dakar, Gorée, and Rufisque in light grey). The area of Colonial Influence stretches from the mouth of the Senegal River (Walo) to southeast Senegal, and includes the pre-colonial kingdoms of Baol, Cayor, Jolof, and Futa Toro, mainly inhabited by Wolof groups. The kingdoms of Sine and Salum, inhabited by a majority of Serer people, are taken into account separately. The macro-region of the Casamance and Southeast includes the area south of the Gambia River and east of the region of Colonial Influence. Finally, the Gambia and Kayes (in today's Mali) are included as separate regions. The underlined labels represent pre-colonial kingdoms, while those in italics show areas inhabited by the Serer and Wolof groups. The dotted area shows were peanut production became most prominent after the 1840s. Dotted lines represent rivers and water streams. Finally, the bars show the number of individuals that we could include in our sample from each region (see legend).

Sources: Digital map elaborated by the authors.

Our work is based on a two-step methodology. First, we estimate basic human capital by relying on the age-heaping technique. We estimate levels of numeracy for a number of macro-regions within Western Sudan, separately for Christians and Muslims, between 1770 and 1900. Western Sudan is defined as the area including Senegambia (today's Senegal and Gambia) and the region of Kayes, in modern-day Western Mali, which was called French Sudan during the colonial period. Second, we explore the determinants of regional human capital formation by drawing on the existing literature about factors that might have influenced the economic fortunes of West African regions before the turn of the twentieth century.

This new quantitative evidence suggests that the influence of European trade and early colonialism on human capital growth was heterogeneous 
and depended to a large extent on local conditions, factor endowments, and institutions (Austin 2008a, 2010). This heterogeneity is clearly shown by human capital indicators at the regional level within Western Sudan. Considering Joseph E. Inikori's (2007) view, we first assess the hypothesis that the slave trade brought about a disintegration of Senegambia's market, as the coastal regions became more specialized and integrated into the Atlantic economy, while inner areas developed less dynamically. Next, we study whether this pattern was reinforced by the impact of domestic slavery, as well as French military campaigns in the early phases of colonization - before the Scramble for Africa. Finally, we argue that Inikori's hypothesis of interregional divergence can be expanded to take into account the rise of other trades, such as the peanut trade, after slavery was formally abolished during the first half of the nineteenth century.

Indeed, the twofold analysis of numeracy and qualitative evidence suggests that economic incentives motivated by European demand for cash crops had different impacts across West African regions, depending on factor endowments and, in turn, the organization of peanut production itself. On the one hand, relatively high population densities, a more favorable climate, the influx of seasonal migrant labor from northern regions, and the limited reliance on slaves favored African producers in coastal regions (e.g., in Sine and Salum). On the other hand, inner regions (e.g., Cayor and Jolof) reacted to the incentives induced by cash crops by relying on slaves and extensive agriculture. This, together with the emigration of their labor force, growing regional conflicts, and French early occupation further limited human capital development.

This evidence shows that European contact had a heterogeneous impact on West African populations. Some West Africans benefitted, growing cash crops and fostering the growth of their human capital. Other groups and regions, however, suffered from European contact. The value added of this study is that, for the first time, these patterns can be traced over time. With our methodology, we can assess West African human capital development from the late-eighteenth to the late-nineteenth century, whereas other quantitative sources or approaches often fail to do so. By gaining insights into the dynamics and heterogeneity of West African development, we also take an important step beyond a "compression" of African economic history (Austin 2008b; Jerven 2015).

\section{WEST AFRICA: EUROPEAN CONTACT AND ECONOMIC DEVELOPMENT BEFORE 1900}

The economic history of West Africa helps to frame the investigation of the impact of European trade, slavery, and early colonialism on human 
capital development in Western Sudan. An aspect that we will assess later is the heterogeneity of regional developments within this region. Indeed, some of the existing quantitative accounts of pre-colonial and colonial West Africa provide a gloomy view on the role played by Europeans, whereas other contributions point out more positive aspects.

Inikori (2007) claims that the rise of the Atlantic economy in the eighteenth century prompted the growth of a regional divide within Western Africa. Prior to European contact, West Africa had experienced the rise of a well-integrated regional market. After the establishment of European outposts, however, the coastal regions of West Africa became more connected to the Atlantic economy, whereas the interior was more isolated and experienced growing conflicts and slave raids, following a growing demand for slaves from the Americas (see Richardson 1989 on the evolution of Atlantic slave trades between 1700 and 1810). Klas Rönnbäck (2015) critically discussed the hypothesis that slavery was an important determinant of the pattern of regional development within the area. He finds that slavery had only a small influence on total agricultural production in the Gold Coast, mostly to feed slaves and crews, although this small impact did tend to be concentrated in the coastal regions. Since we explore the effect of peanut farming on numeracy later, we expect to find a heterogeneous impact as well.

Scholars have explored a number of positive developments linked to European influence and trade. For example, Gareth Austin (2016) has pointed out the possibility that West African farmers might have benefitted from the new trading opportunities provided by European trade networks. Expanding peanut production after the 1840s in the Gambia, Sine-Salum, the Rufisque and Petite-Cote region, in Cayor and along the lower Senegal was done mainly by free labor. ${ }^{1}$ It also stimulated the development of a host of activities, such as transportation, marketing, and food provision (Atmore 1985; Brooks 1975; Searing 1993, pp. 187-8). However, this latter point is still a debated issue in the context of the rise of peanut production in West Africa. Evidence from early colonial Kano in Nigeria shows that African initiatives were central to the rise of peanut as a cash crop, but also that slavery was heavily used to increase production (Salau 2010). Joye L. Bowman (1987) confirmed the importance of slavery for the rise of groundnut production in Portuguese Guinea, which was done on relatively large estates by African producers. She also stressed that migrant labor was important; yet, these workers could

\footnotetext{
${ }^{1}$ Figures on the importance of this trade are not available for the whole region. Brooks (1975) shows that the quantity of nuts exported from Gambia grew from 213 baskets in 1834 to 11,095 tons in 1851. Similarly, Moitt (1989) argues that peanut production in the regions of Cayor and Baol (Senegal) rose from 1 to 5,000 tons between 1840 and 1850 .
} 
not accumulate property: "more often than not [...] the workers had very little of their peanut harvest left after clearing their debt [with the landlord]" (Bowman 1987, p. 97).

Evidence on the economic and social impact of the peanut trade in Senegambia is more controversial with respect to other West African regions. Bernard Moitt (1989) argued that slavery played an important role. However, his evidence is based on a clear regional pattern. Slaves were primarily imported from Western Mali (French Sudan) through a route following the Senegal River, and they ended up in the peanut basin of Cayor and Baol. Furthermore, Moitt made a clear connection between Wolof societies and families, who inhabited mostly the northwest of Senegambia, and the use of slaves. Technological constraints and factor endowments did not allow an increase in productivity, so that extensive growth based on more land and more labor was the only chance to reap the benefits of increasing foreign demand.

Factor endowments and the organization of society itself differed in other regions of Senegal, such as Sine and Salum. Babacar Fall (2010) provides qualitative evidence suggesting that the impact of peanut production on society and the economy of the Senegambia was positive, especially in the coastal regions of today's Senegal, such as Salum. First, he notes that production was often organized at the family level, using labor from the household, which was possible given high population density in some rural regions of today's Senegal (high population densities in some regions are confirmed by Rousseau 1929, pp. 400-3).

Fall also argues that the growth of peanut exports increased the peasants' living standard. According to him, up to 1930, peasants of some rural areas in Senegal earned more than laborers in Dakar (idem, p. 59). Furthermore, Fall (2010) notes that even though labor migrations occurred in Senegambia before 1900, there was a clear regional pattern. People migrated temporarily from the north and northeast of Senegal (Jolof and Cayor mainly) towards the south, such as Kaolack in the Salum region (idem, p. 62).

The main hypothesis that slavery, early colonialism, and European trade brought about a growing regional divide - especially as peanut production benefitted only specific groups and regions - can be assessed quantitatively by studying the development of human capital in the area of Senegal, Gambia, and Western Mali. The French outposts of St. Louis and Gorée, along the coast of today's Senegal, as shown in Figure 1, grew quickly as important centers for slavery and trade during the eighteenth century (Becker et al. 1983). Their growing integration in the Atlantic 
economy fits Inikori's hypothesis of economic divergence between the coast and the interior of West Africa: Gorée became particularly important in the eighteenth century, as the island was used to gather slaves who would soon be deported to the Americas (Knight-Baylac 1970, 1977). Consistent with the evidence offered by James F. Searing (1993), the data we discuss later shows that captives in the two French outposts often performed semi-skilled occupations such as carpenters, sailors, and textile workers among men and laundrywomen, spinners, and cleaners among women. This pattern of specialization was brought about by the presence of very few Europeans on the Atlantic coast, who needed rather skilled labor to be used within the growing market economy that was brought about by the Atlantic slave trade.

The long-term contact with Europeans made society along the West coast of Senegambia quite diverse and mixed. In 1794, the freeborn inhabitants of Gorée and St. Louis were formally granted French citizenship, extended in 1848 to Rufisque and Dakar (Idowu 1969). These towns, the so-called Four Communes, had mixed populations, which can be divided in three main categories: Europeans (mostly French), black Africans from Western Sudan and descendants of African women and European traders (called métis). The latter would later become a distinct class of the Four Communes, known as the habitants. They enjoyed French citizenship, inherited their European fathers' names and to a large extent they also inherited their fathers' European culture due to their involvement in business, attendance of schools, and practice of Catholicism (Searing 1993). Therefore, we expect to observe high values of numeracy in these regions.

Other aspects of colonialism, such as military expansion and the violent annexation of new territory, clearly had a more negative impact on Africans. During the mid-nineteenth century, the Four Communes served as bases in France's expansion in Western Sudan led by governors Faidherbe and Brier de L'Isle. The French first annexed part of the region of Cayor and established a few posts along the Senegal River by defeating the Walo. During the 1880s and early 1890 s, other regions south and southeast of Gorée and St. Louis became part of the French colony. By 1891, the last pockets of independence were eliminated in Jolof, Futa Toro, and Cayor (Robinson 2000, p. 63). Salum was also formally under French rule, although France's presence "was minimal. [...] In 1890, France was officially represented in the cercle of Sine-Salum by one lone Administrator. But French military power was in the wings, always available, though seldom visible" (Klein 1968, p. 150; Barry 1998, who describes France's involvement in Sine-Salum as "half-hearted"). The 
Dakar-Saint-Louis railway, completed in 1885, allowed further control over the new territories. Casamance was the last region to be annexed by the French during the early twentieth century. We expect to observe a negative relationship between military conflicts and numeracy in our analysis later.

Besides European trade and early contact, local endowments shaped the features of West African societies and, as a result, the way that they reacted to external opportunities and constraints. In particular, the difference between the Wolof society and that of the Serer stands out (Barry 1998, pp. 16-17). The Wolof inhabited the area of today's metropolitan Dakar and the regions of Cayor, Baol, Walo, Futa Toro, and Jolof. Highly mobile, they were characterized by a hierarchical society. Slaves were used to cope with the poor quality of soils in the dry savanna environment, as well as the limited availability of labor to dig wells (Searing 1993, p. 3). By contrast, the Serer lived in the heavily forested and wellwatered region of Sine and, especially, Salum. They were able to use land intensively and more than once a year, due to their heavy reliance on manure produced by cattle that were held in soon-to-be-cultivated fields.

South of the Gambia, the Joola lived in the western area of the Casamance. Because of their location along the coast, a large share of their population was enslaved and deported to the Americas. Finally, the Mandingos were heirs to the great Mali Empire and inhabited a large area that stretched between Mali and southeast Senegal, including portions of both Portuguese and French Guinea to the south. They had a long history of owning and maintaining slaves and were characterized as a society based on castes with a comparatively inefficient agricultural technology (Curtin 1975, p. 29).

The different societies and polities of Senegambia experienced several changes after the first contact with Europeans. First, the rise of the slave trade in the eighteenth century brought about growing instability in the kingdoms of the former Jolof Empire, where the response to the growing demand for slaves initiated a violent age of warlords, called ceddo (Getz 2004, pp. 12-13). During the nineteenth century, the ceddo aristocracy fought the rise of the marabouts (Islamic religious leaders) following waves of Muslim migration from the region north of the Senegal River, which put even more pressure on the cohesiveness of pre-colonial kingdoms. The hierarchical structure of the Wolof likely favored the rise of the ceddo and of internal conflicts, whereas more stability and cohesiveness 
in Sine and Salum were favored by the equal and uniform society of the Serer. As Boubacar Barry (1998, pp. 87-88) notes, "“...] since the history of $\operatorname{Siin}^{2}$ was shaped by the narrowness of its boundaries, the context of generalized violence forced it to grow even more isolationist and to develop an agricultural system of shifting cultivation in a bid to maintain internal cohesion." According to Barry, the society of Salum was slightly more mixed than that of Sine given its large territory, which helped Islam to gain strength during the late-nineteenth century. Yet, this shift was not accompanied by violent campaigns by the French to maintain control of their territory, as in Cayor and Futa Toro. Instead, in Sine and Salum, the concurrent development of Islam and peanut cultivation, carried out by African peasants on small landholdings, helped many of them to avoid the pillaging of ceddo rulers.

While differences among West African societies were hardly static, we explore whether some of these pre-colonial societal features and factor endowments might have influenced the response to incentives brought about by Europeans. The study of human capital trends in West Africa before 1900 has long remained an uncharted territory, and our estimates provide a way to assess some of the aforementioned hypotheses on the role played by European trade, slavery, and factor endowments on the long-term development of human capital in West Africa.

\section{DATA SOURCES AND METHODOLOGY}

The French colonial administration in Senegal was quite active in collecting information about the population of Gorée, and a number of census lists and electoral registers survived in the National Archives of Senegal (Dakar). While the censuses of Gorée and St. Louis are known to scholars and have been studied before (Becker et al. 1983), to our knowledge the underlying micro data have not been used to study human capital development. In particular, we use individual-level records organized by birth cohort to estimate long-term trends in numeracy in three different periods: $1770-1799,1800-1849$, and 1850-1899. ${ }^{3}$ Although the sources do not allow us to draw a well-defined line between the métis (FrancoAfrican Creoles) and African groups, the history of Senegambia suggests that religion can be used as a proxy for differentiating between them

\footnotetext{
${ }^{2}$ A different way of spelling Sine.

${ }^{3}$ Although we refer to half-centuries of birth, data for the first period allow us to cover only the years from 1770 to 1799 .
} 
in broad terms, or at least to differentiate between Christian Europeans (a tiny minority) and métis people on the one hand and Muslim West Africans on the other. ${ }^{4}$

We drew data for analysis mainly from census lists, which cover the early nineteenth to early twentieth centuries. We observed a large portion of the population recorded. We took all the individuals available through the sources. Different "census years" sometimes refer to different stages in preparation of the same census, so that repetition is very unlikely; yet, we also avoided repetition by checking the names of the people included in the dataset. ${ }^{5}$ Table 1 provides more details on the sources used and the number of observations available for each year. In addition, we collected evidence from electoral registers that started in 1851, which include information on the population of the Four Communes.

We use the terms "human capital" and "numeracy" as synonyms in the following discussion even though the concept of human capital may include other components. Although economic historians are well aware of the importance of human capital for economic growth and development (Allen 2011; Baten and van Zanden 2008; Temple and Voth 1998), they must often rely on imperfect measures of educational quality because information on numerical skills and genuine ability is unavailable. The most common proxy for educational outcomes from a historical perspective is literacy. Yet, literacy rates do not always represent the quality of education, and several problems with this index have been highlighted by the literature (A'Hearn, Baten, and Crayen 2009). Taking these matters into consideration, researchers have tried to develop new measures of human capital, such as the production of books, which proxies for advanced literacy (Baten and van Zanden 2008).

A recent line of inquiry has developed an approach to measuring basic quantitative skills, reaching back to the medieval period and earlier. Brian A'Hearn, Joerg Baten, and Dorothee Crayen have found that the basic ability to count and complete simple calculations is negatively correlated with age heaping, that is, the tendency to report one's own age as rounded numbers such as 0 and 5 . The extent of heaping for a given population can be summarized by the Whipple Index (Shryock and Siegel 1976),

\footnotetext{
${ }^{4}$ The use of religion to differentiate between Europeans (and the métis) and Africans seems to be a robust proxy: figures elaborated from the 1835 census suggest that, in St. Louis, 97 percent of free Africans and 99 percent of slaves were Muslims (Becker et al. 1983).

${ }^{5}$ As a caveat, it is worth noting that some parts of the censuses were not accessible due to bad preservation status (e.g., excessive moisture and mould).
} 
TABLE 1

SOURCES OF INDIVIDUAL DATA SORTED BY YEAR AND TYPE (RECORDED IN GORÉE AND DAKAR)

\begin{tabular}{|c|c|c|c|}
\hline \multirow[b]{2}{*}{ Year } & \multicolumn{2}{|c|}{ Source } & \multirow[b]{2}{*}{ Total } \\
\hline & Census Survey & Electoral Register & \\
\hline 1832 & 1,194 & & 1,194 \\
\hline 1835 & 1,115 & & 1,115 \\
\hline 1836 & 27 & & 27 \\
\hline 1843 & 10 & & 10 \\
\hline 1844 & 146 & & 146 \\
\hline 1845 & 120 & & 120 \\
\hline 1846 & 1,368 & & 1,368 \\
\hline 1847 & 1,367 & & 1,367 \\
\hline 1848 & 227 & & 227 \\
\hline 1851 & & 547 & 547 \\
\hline 1867 & 327 & & 327 \\
\hline 1868 & 46 & & 46 \\
\hline 1869 & 23 & & 23 \\
\hline 1876 & 129 & & 129 \\
\hline 1880 & 256 & & 256 \\
\hline 1887 & & 243 & 243 \\
\hline 1888 & 25 & & 25 \\
\hline 1891 & 862 & & 862 \\
\hline 1904 & 84 & & 84 \\
\hline 1909 & 590 & & 590 \\
\hline 1913 & & 1,722 & 1,722 \\
\hline 1914 & 601 & & 601 \\
\hline 1921 & 313 & & 313 \\
\hline Total & 8,830 & 2,512 & 11,342 \\
\hline
\end{tabular}

Source: National Archives of Senegal, Dakar: Electoral registers were found in the 3G262 and 3G265 folders, and were collected in 1851, 1887, and 1913; census lists were found in folders from $3 \mathrm{G} 2120$ to $3 \mathrm{G} 2140$ and in folders $22 \mathrm{G} 29$ and $22 \mathrm{G} 34$, and include enumerations collected between 1832 and 1921.

which is the ratio of the observed frequency of ages ending in 0 or 5 to the frequency predicted by assuming a uniform distribution of terminal digits (one-fifth of total individuals), as described in Equation 1. The ABCC index, a linear transformation of the Whipple Index suggested by A'Hearn, Baten, and Crayen (2009), represents the share of the population able to report their own age exactly and ranges between 0 and 100, as described in Equation 2. 


$$
\begin{gathered}
W I=\frac{\sum\left(n_{25}+n_{30}+\ldots \ldots+n_{55}+n_{70}\right)}{(1 / 5) \sum\left(n_{23}+n_{24}+\ldots \ldots . .+n_{70}+n_{71}+n_{72}\right)} \times 100^{6} \\
A B C C=\left(1-\frac{(W I-100)}{400}\right) \times 100 .
\end{gathered}
$$

By exploring the extent of age heaping, numeracy can be inferred from a large variety of sources: census lists and household surveys, marriage registers, court records, and death registers are only some of the sources that can be used to reconstruct age heaping through historical samples. ${ }^{7}$

We base our work on a two-step methodology. First, we estimate basic human capital for a number of macro-regions and half-century periods within Western Sudan by documenting age-heaping. Second, we explore the determinants of regional human capital formation in this panel by drawing on the literature discussed in the previous section.

The first step works as follows. Senegal is divided into seven macroregions, based on characteristics of West African societies and kingdoms and the nature and intensity of interaction with Europeans. Figure 1 provides more detail. The region of "direct influence" is defined as the coastal area stretching from Rufisque on the petite côte up to St. Louis on the mouth of the Senegal River, including Dakar and the small island of Gorée. These Four Communes, as we have explained earlier, were characterized by long-term contact (1650-1900) between Europeans and West Africans due to commercial ties. There, European and local populations coexisted and often mixed. Next, the region of "colonial influence" is defined as the area that was inhabited mainly by Wolof people, including Walo, Cayor, Baol, Jolof, and Futa Toro. This area was characterized by major slave deportations as well as early colonial military campaigns, wars, and occupation. Third and fourth, the regions of Sine and Salum, south of Baol and north of the Gambia River on the west coast, were mostly inhabited by Serer groups and were only marginally touched by the military campaigns of the late nineteenth century. Fifth, Casamance, south of the Gambia and southeast Senegal, was annexed to Senegal later than any other regions and inhabited mostly by Jola and Mandingos (see Appendix Table 1 for an overview on how we recoded regions within Senegal). In addition to Senegal, we are able to obtain

\footnotetext{
${ }^{6} n$ is the frequency of observations for each age reported.

${ }^{7}$ Some of these sources need basic adjustments to be used to calculate numeracy. See Crayen and Baten (2010).
} 
numeracy levels of people born in the Gambia and in the region of Kayes, in today's Mali, east of the upper Senegal River.

To calculate regional numeracy from micro-level data, we assign each individual in the sample to these areas according to their place of birth. Besides information on the latter, our database includes data on each individual's age, occupation, gender, captivity, and religion. We classify individuals according to their type of occupation following the taxonomy suggested by Alan Armstrong (1974), which is, in the case of our African evidence, virtually identical to what one would obtain by using HISCLASS (Leeuwen and Maas 2011). ${ }^{8}$

We estimate regional numeracy trends by following Joerg Baten and Johan Fourie (2015). Specifically, we estimate a regression in which the dependent variable equals 1 if the person has an age that does not end in 0 or 5, and the key independent variables are interaction terms that include religion (to reflect whether the background of the concerned individual was Creole or mostly African), the region of birth, and the half-century of birth to capture regional $\mathrm{ABCC}$ trends over the long run. ${ }^{9}$ The interaction terms will capture the premium on numeracy (expressed relative to the constant of the model) for each background-region-period chosen; the control variables that we include in the regressions will help to limit the influence of potential sources of selectivity. In other words, this firststep-regression approach is preferable to simple averages for obtaining numeracy values. For example, if the sample referring to a specific region and period was characterized by a high share of slaves, while this was not the case for the underlying population, the value of numeracy obtained through simple averages for that particular region and time would be biased.

\section{FIRST-STEP RESULTS: HUMAN CAPITAL TRENDS} IN WESTERN SUDAN, 1770-1900

The estimates of regional numeracy trends are based on the regressions reported in Table $2 .{ }^{10}$ To obtain regional ABCC figures, the religion-region-time coefficients are added to the value of the reference category (the constant refers to an unskilled, free Christian born between

\footnotetext{
${ }^{8}$ HISCLASS stands for Historical International Social Class Scheme. We also include a category for farmers to assess whether access to better nutrition fostered basic cognitive skills.

${ }^{9}$ A half-century refers to a 50-year interval; for example, we refer to 1850 to indicate people born between 1850 and 1899 .

${ }^{10}$ Appendix Table 2 provides an overview of the regional sample by half-century of birth and religion. Gambia is not included in Table 2's results, as we exclude evidence based on less than 30 individual observations per region.
} 
TABLE 2

ESTIMATING REGIONAL TRENDS IN NUMERACY

\begin{tabular}{|c|c|c|c|c|c|}
\hline $\begin{array}{l}\text { Econometric Model } \\
\text { Dependent Variable } \\
\text { Data Excluded }\end{array}$ & $\begin{array}{c}(1) \\
\text { Logit } \\
\text { Numerate } \\
\text { None }\end{array}$ & $\begin{array}{c}(2) \\
\text { Probit } \\
\text { Numerate } \\
\text { None }\end{array}$ & $\begin{array}{c}\text { (3) } \\
\text { LPM } \\
\text { Numerate } \\
\text { None }\end{array}$ & $\begin{array}{c}\text { (4) } \\
\text { LPM } \\
\text { Numerate } \\
\text { El. Registers }\end{array}$ & $\begin{array}{c}(5) \\
\text { LPM } \\
\text { Numerate } \\
\text { Slaves }\end{array}$ \\
\hline Female & $\begin{array}{l}-2.03 \\
(0.240)\end{array}$ & $\begin{array}{l}-2.05 \\
(0.243)\end{array}$ & $\begin{array}{l}-2.25 \\
(0.206)\end{array}$ & $\begin{array}{c}-3.78^{* *} \\
(0.049)\end{array}$ & $\begin{array}{c}-0.2325 \\
(0.917)\end{array}$ \\
\hline Gender unknown & $\begin{array}{c}0.54 \\
(0.791)\end{array}$ & $\begin{array}{c}0.89 \\
(0.659)\end{array}$ & $\begin{array}{c}0.62 \\
(0.750)\end{array}$ & $\begin{array}{l}-4.65^{*} \\
(0.060)\end{array}$ & $\begin{array}{l}3.0894 \\
(0.177)\end{array}$ \\
\hline Age $23-32$ & $\begin{array}{c}1.62 \\
(0.283)\end{array}$ & $\begin{array}{c}1.65 \\
(0.269)\end{array}$ & $\begin{array}{c}1.47 \\
(0.276)\end{array}$ & $\begin{array}{c}0.69 \\
(0.699)\end{array}$ & $\begin{array}{l}1.9939 \\
(0.182)\end{array}$ \\
\hline Source: Electoral register bias & $\begin{array}{c}11.82 * * \\
(0.021)\end{array}$ & $\begin{array}{l}12.39^{* *} \\
(0.020)\end{array}$ & $\begin{array}{l}13.85^{* *} \\
(0.024)\end{array}$ & & $\begin{array}{c}14.1979 * * \\
(0.022)\end{array}$ \\
\hline Christian $\mathrm{x}$ slave bias & $\begin{array}{l}-1.45 \\
(0.749)\end{array}$ & $\begin{array}{l}-1.23 \\
(0.787)\end{array}$ & $\begin{array}{l}-1.35 \\
(0.771)\end{array}$ & $\begin{array}{l}-1.94 \\
(0.679)\end{array}$ & \\
\hline Christian x slavery status NA & $\begin{array}{l}-2.65 \\
(0.548)\end{array}$ & $\begin{array}{l}-2.34 \\
(0.602)\end{array}$ & $\begin{array}{l}-2.55 \\
(0.583)\end{array}$ & $\begin{array}{c}-4.07 \\
(0.385)\end{array}$ & \\
\hline Muslim x slave bias & $\begin{array}{c}12.72 * * * \\
(0.000)\end{array}$ & $\begin{array}{c}13.19 * * * \\
(0.000)\end{array}$ & $\begin{array}{c}14.46 * * * \\
(0.000)\end{array}$ & $\begin{array}{c}13.53 * * * \\
(0.000)\end{array}$ & \\
\hline Muslim x free-born & $\begin{array}{c}8.35 \\
(0.157)\end{array}$ & $\begin{array}{c}8.84 \\
(0.144)\end{array}$ & $\begin{array}{c}9.78 \\
(0.125)\end{array}$ & $\begin{array}{c}8.49 \\
(0.185)\end{array}$ & \\
\hline Religion NA x slave bias & $\begin{array}{l}7.88^{* * *} \\
(0.005)\end{array}$ & $\begin{array}{l}8.11^{* * *} \\
(0.004)\end{array}$ & $\begin{array}{c}8.35^{* * *} \\
(0.005)\end{array}$ & $\begin{array}{l}7.92 * * * \\
(0.008)\end{array}$ & \\
\hline Religion NA x free-born & $\begin{array}{c}3.55 \\
(0.353)\end{array}$ & $\begin{array}{c}3.70 \\
(0.348)\end{array}$ & $\begin{array}{c}3.77 \\
(0.384)\end{array}$ & $\begin{array}{c}3.18 \\
(0.469)\end{array}$ & \\
\hline Occupation unknown & $\begin{array}{l}-3.20 \\
(0.114)\end{array}$ & $\begin{array}{l}-3.21 \\
(0.118)\end{array}$ & $\begin{array}{l}-3.47^{*} \\
(0.094)\end{array}$ & $\begin{array}{l}-3.18 \\
(0.151)\end{array}$ & $\begin{array}{c}-5.8208^{* *} \\
(0.044)\end{array}$ \\
\hline Intermediate & $\begin{array}{c}2.18 \\
(0.481)\end{array}$ & $\begin{array}{c}2.10 \\
(0.500)\end{array}$ & $\begin{array}{c}2.16 \\
(0.485)\end{array}$ & $\begin{array}{c}4.38 \\
(0.217)\end{array}$ & $\begin{array}{l}0.6088 \\
(0.862)\end{array}$ \\
\hline Skilled & $\begin{array}{l}-1.40 \\
(0.514)\end{array}$ & $\begin{array}{l}-1.24 \\
(0.563)\end{array}$ & $\begin{array}{l}-1.52 \\
(0.470)\end{array}$ & $\begin{array}{l}-1.63 \\
(0.493)\end{array}$ & $\begin{array}{c}-2.5126 \\
(0.360)\end{array}$ \\
\hline Partly skilled & $\begin{array}{l}-1.12 \\
(0.694)\end{array}$ & $\begin{array}{l}-1.18 \\
(0.686)\end{array}$ & $\begin{array}{l}-1.14 \\
(0.711)\end{array}$ & $\begin{array}{l}-1.75 \\
(0.597)\end{array}$ & $\begin{array}{l}2.6647 \\
(0.536)\end{array}$ \\
\hline Professional & $\begin{array}{c}10.22 \\
(0.209)\end{array}$ & $\begin{array}{c}8.92 \\
(0.245)\end{array}$ & $\begin{array}{c}8.72 \\
(0.205)\end{array}$ & $\begin{array}{c}22.03 * * * \\
(0.007)\end{array}$ & $\begin{array}{l}7.6204 \\
(0.288)\end{array}$ \\
\hline Farmer & $\begin{array}{c}2.19 \\
(0.619)\end{array}$ & $\begin{array}{c}2.56 \\
(0.540)\end{array}$ & $\begin{array}{c}0.86 \\
(0.790)\end{array}$ & $\begin{array}{c}18.80 * * * \\
(0.000)\end{array}$ & $\begin{array}{c}-0.6623 \\
(0.858)\end{array}$ \\
\hline Christian $\mathrm{x}$ direct influence $\mathrm{x} 1750$ & $\begin{array}{c}-15.82 * * \\
(0.023)\end{array}$ & $\begin{array}{c}-16.68^{* *} \\
(0.018)\end{array}$ & $\begin{array}{c}-18.54 * * \\
(0.014)\end{array}$ & $\begin{array}{c}-21.00 * * * \\
(0.007)\end{array}$ & $\begin{array}{c}-21.3373 * * * \\
(0.009)\end{array}$ \\
\hline Christian $\mathrm{x}$ direct influence $\mathrm{x} 1800$ & $\begin{array}{c}-13.80 * * * \\
(0.002)\end{array}$ & $\begin{array}{c}-14.32 * * * \\
(0.002)\end{array}$ & $\begin{array}{c}-16.42 * * * \\
(0.001)\end{array}$ & $\begin{array}{c}-17.72 * * * \\
(0.001)\end{array}$ & $\begin{array}{c}-16.7382 * * * \\
(0.001)\end{array}$ \\
\hline Christian $x$ France and others $x 1850$ & $\begin{array}{l}-8.44 \\
(0.345)\end{array}$ & $\begin{array}{c}-8.14 \\
(0.372)\end{array}$ & $\begin{array}{l}-8.90 \\
(0.345)\end{array}$ & $\begin{array}{l}-11.70 \\
(0.217)\end{array}$ & $\begin{array}{c}-8.4742 \\
(0.371)\end{array}$ \\
\hline Christian x Casamance and East x 1850 & $\begin{array}{l}-11.94 \\
(0.131)\end{array}$ & $\begin{array}{l}-12.18 \\
(0.140)\end{array}$ & $\begin{array}{l}-12.88 \\
(0.159)\end{array}$ & $\begin{array}{l}-13.15 \\
(0.151)\end{array}$ & $\begin{array}{c}-12.7137 \\
(0.167)\end{array}$ \\
\hline Christian $\mathrm{x}$ region NA $\mathrm{x} 1750$ & $\begin{array}{c}-17.35^{* * *} \\
(0.008)\end{array}$ & $\begin{array}{c}-17.84 * * * \\
(0.008)\end{array}$ & $\begin{array}{c}-20.43 * * * \\
(0.004)\end{array}$ & $\begin{array}{c}-23.03 * * * \\
(0.002)\end{array}$ & $\begin{array}{c}-25.5620 * * * \\
(0.001)\end{array}$ \\
\hline Christian $\mathrm{x}$ region NA $\mathrm{x} 1800$ & $\begin{array}{c}-14.45^{* * *} \\
(0.009)\end{array}$ & $\begin{array}{c}-15.12 * * * \\
(0.007)\end{array}$ & $\begin{array}{c}-16.95^{* * * *} \\
(0.004)\end{array}$ & $\begin{array}{c}-18.77 * * * \\
(0.002)\end{array}$ & $\begin{array}{c}-18.8595 * * * \\
(0.002)\end{array}$ \\
\hline
\end{tabular}


TABLE 2 (CONTINUED)

ESTIMATING REGIONAL TRENDS IN NUMERACY

\begin{tabular}{|c|c|c|c|c|c|}
\hline $\begin{array}{l}\text { Econometric Model } \\
\text { Dependent Variable } \\
\text { Data Excluded }\end{array}$ & $\begin{array}{c}(1) \\
\text { Logit } \\
\text { Numerate } \\
\text { None }\end{array}$ & $\begin{array}{c}(2) \\
\text { Probit } \\
\text { Numerate } \\
\text { None }\end{array}$ & $\begin{array}{c}(3) \\
\text { LPM } \\
\text { Numerate } \\
\text { None }\end{array}$ & $\begin{array}{c}\text { (4) } \\
\text { LPM } \\
\text { Numerate } \\
\text { El. Registers }\end{array}$ & $\begin{array}{c}(5) \\
\text { LPM } \\
\text { Numerate } \\
\text { Slaves }\end{array}$ \\
\hline Christian $\mathrm{x}$ region NA x 1850 & $\begin{array}{l}-3.86 \\
(0.563)\end{array}$ & $\begin{array}{l}-3.84 \\
(0.569)\end{array}$ & $\begin{array}{c}-4.19 \\
(0.530)\end{array}$ & $\begin{array}{l}-4.89 \\
(0.462)\end{array}$ & $\begin{array}{c}-4.0444 \\
(0.550)\end{array}$ \\
\hline Muslim x Mali x 1850 & $\begin{array}{c}-43.18^{* * * *} \\
(0.000)\end{array}$ & $\begin{array}{c}-45.55 * * * \\
(0.000)\end{array}$ & $\begin{array}{c}-53.70^{* * *} \\
(0.000)\end{array}$ & $\begin{array}{c}-53.55^{* * * *} \\
(0.000)\end{array}$ & $\begin{array}{c}-53.9129 * * * \\
(0.000)\end{array}$ \\
\hline Muslim x direct influence x 1750 & $\begin{array}{c}-23.73 * * * \\
(0.006)\end{array}$ & $\begin{array}{c}-24.35 * * * \\
(0.005)\end{array}$ & $\begin{array}{c}-27.87 * * * \\
(0.002)\end{array}$ & $\begin{array}{c}-29.19^{* * *} \\
(0.002)\end{array}$ & \\
\hline Muslim x direct influence x 1800 & $\begin{array}{c}-21.18^{* * *} \\
(0.000)\end{array}$ & $\begin{array}{c}-22.50^{* * * *} \\
(0.000)\end{array}$ & $\begin{array}{c}-25.62 * * * \\
(0.000)\end{array}$ & $\begin{array}{c}-26.75^{* * *} \\
(0.000)\end{array}$ & $\begin{array}{c}-19.4531 \text { *** } \\
(0.001)\end{array}$ \\
\hline Muslim x direct influence x 1850 & $\begin{array}{c}-9.54 * * \\
(0.016)\end{array}$ & $\begin{array}{c}-9.97 * * \\
(0.014)\end{array}$ & $\begin{array}{c}-10.29 * * \\
(0.016)\end{array}$ & $\begin{array}{c}-9.99 * * \\
(0.020)\end{array}$ & $\begin{array}{c}-10.2505^{* *} \\
(0.017)\end{array}$ \\
\hline Muslim x colonial influence x 1750 & $\begin{array}{c}-26.25^{* * *} \\
(0.000)\end{array}$ & $\begin{array}{c}-26.85 * * * \\
(0.000)\end{array}$ & $\begin{array}{c}-30.37 * * * \\
(0.000)\end{array}$ & $\begin{array}{c}-32.30^{* * * *} \\
(0.000)\end{array}$ & $\begin{array}{c}-20.6706^{* *} \\
(0.039)\end{array}$ \\
\hline Muslim x colonial influence x 1800 & $\begin{array}{c}-27.45^{* * *} \\
(0.000)\end{array}$ & $\begin{array}{c}-27.95 * * * \\
(0.000)\end{array}$ & $\begin{array}{c}-31.93 * * * \\
(0.000)\end{array}$ & $\begin{array}{c}-33.59 * * * \\
(0.000)\end{array}$ & $\begin{array}{c}-44.1887 * * * \\
(0.000)\end{array}$ \\
\hline Muslim x colonial influence x 1850 & $\begin{array}{c}-30.45^{* * *} \\
(0.000)\end{array}$ & $\begin{array}{c}-31.80 * * * \\
(0.000)\end{array}$ & $\begin{array}{c}-36.71 * * * \\
(0.000)\end{array}$ & $\begin{array}{c}-37.79 * * * \\
(0.000)\end{array}$ & $\begin{array}{c}-36.5116^{* * *} \\
(0.000)\end{array}$ \\
\hline Muslim x Casamance and East x 1850 & $\begin{array}{c}-24.03 * * * \\
(0.005)\end{array}$ & $\begin{array}{c}-24.85 * * * \\
(0.006)\end{array}$ & $\begin{array}{c}-27.73 * * \\
(0.010)\end{array}$ & $\begin{array}{c}-28.93 * * * \\
(0.008)\end{array}$ & $\begin{array}{c}-27.8832 * * \\
(0.010)\end{array}$ \\
\hline Muslim $x$ region NA x 1750 & $\begin{array}{c}-27.35^{* * *} \\
(0.000)\end{array}$ & $\begin{array}{c}-28.18^{* * * *} \\
(0.000)\end{array}$ & $\begin{array}{c}-31.66^{* * * *} \\
(0.000)\end{array}$ & $\begin{array}{c}-33.80 * * * \\
(0.000)\end{array}$ & $\begin{array}{c}-22.7961 * * * \\
(0.007)\end{array}$ \\
\hline Muslim $x$ region NA x 1800 & $\begin{array}{c}-30.36^{* * *} \\
(0.000)\end{array}$ & $\begin{array}{c}-31.18^{* * * *} \\
(0.000)\end{array}$ & $\begin{array}{c}-34.77 * * * \\
(0.000)\end{array}$ & $\begin{array}{c}-36.05 * * * \\
(0.000)\end{array}$ & $\begin{array}{c}-33.0572 * * * \\
(0.000)\end{array}$ \\
\hline Muslim $\mathrm{x}$ region NA x 1850 & $\begin{array}{c}-27.50^{* * *} \\
(0.001)\end{array}$ & $\begin{array}{c}-28.80 * * * \\
(0.001)\end{array}$ & $\begin{array}{c}-33.15^{* * * *} \\
(0.004)\end{array}$ & $\begin{array}{c}-33.89 * * * \\
(0.003)\end{array}$ & $\begin{array}{c}-32.5253 * * * \\
(0.004)\end{array}$ \\
\hline Muslim x Sine x 1750 & $\begin{array}{c}-19.86^{* *} \\
(0.025)\end{array}$ & $\begin{array}{c}-20.29 * * \\
(0.022)\end{array}$ & $\begin{array}{c}-24.33 * * * \\
(0.004)\end{array}$ & $\begin{array}{c}-26.44 * * * \\
(0.002)\end{array}$ & \\
\hline Muslim x Sine x 1800 & $\begin{array}{c}-20.68^{* *} \\
(0.033)\end{array}$ & $\begin{array}{c}-21.10^{* *} \\
(0.028)\end{array}$ & $\begin{array}{c}-25.87 * * * \\
(0.003)\end{array}$ & $\begin{array}{c}-27.88^{* * * *} \\
(0.002)\end{array}$ & \\
\hline Muslim x Salum x 1800 & $\begin{array}{c}-25.32 * * * \\
(0.009)\end{array}$ & $\begin{array}{c}-25.87 * * \\
(0.011)\end{array}$ & $\begin{array}{c}-30.33 * * * \\
(0.003)\end{array}$ & $\begin{array}{c}-31.62 * * * \\
(0.002)\end{array}$ & \\
\hline Muslim x Salum x 1850 & $\begin{array}{l}-12.02 \\
(0.160)\end{array}$ & $\begin{array}{l}-12.88 \\
(0.143)\end{array}$ & $\begin{array}{l}-13.04 \\
(0.226)\end{array}$ & $\begin{array}{l}-13.97 \\
(0.200)\end{array}$ & $\begin{array}{c}-13.2398 \\
(0.214)\end{array}$ \\
\hline Constant & & & $\begin{array}{c}88.45^{* * *} \\
(0.000)\end{array}$ & $\begin{array}{c}91.09 * * * \\
(0.000)\end{array}$ & $\begin{array}{c}87.9276^{* * * *} \\
(0.000)\end{array}$ \\
\hline Observations & 8,669 & 8,669 & 8,669 & 6,383 & 6,362 \\
\hline R-squared & & & 0.054 & 0.047 & 0.064 \\
\hline
\end{tabular}

P-values in parentheses.

$* * * \mathrm{p}<0.01, * * \mathrm{p}<0.05, * \mathrm{p}<0.1$

Note: The dependent variable "numerate" is one if an age not ending in 0 or 5 is reported. Marginal effects are reported, expressed in $\mathrm{ABCC}$ percentages. The constant refers to an unskilled, free Christian born between 1850 and 1899 in the region of direct influence (The Four Communes and their surroundings), male, aged 33 to 72 and recorded via census. Survey-year dummies and "gender unknown" dummies are included. The results when the religious group and gender could not be identified (NA) are not reported in the table. Only 8,669 observations from the original dataset remain when the age interval 23-72 is concerned.

Source: See text. 


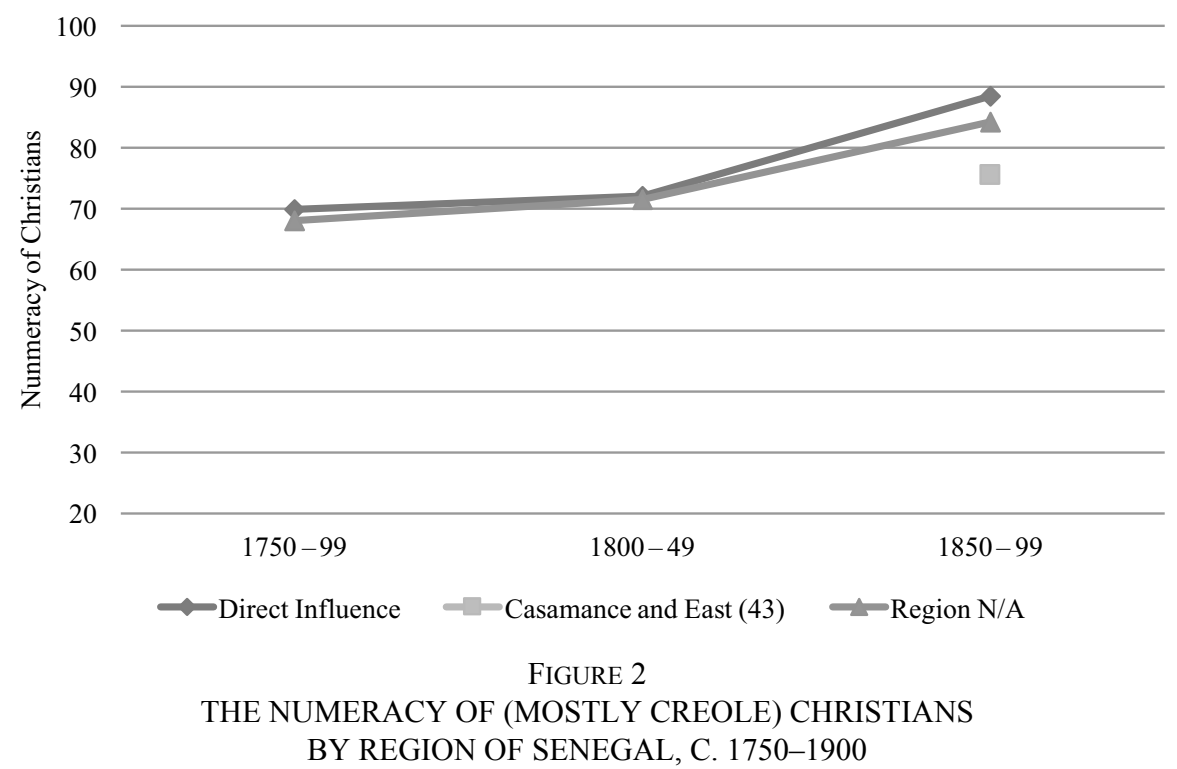

Notes: The ABCC for the region of Casamance and East is based on a small sample of 43 observations during the period 1850-99. "Direct influence" are the four cities at the coast and their surroundings, in which contact with Europeans developed earliest.

Sources: See text.

1850 and 1899 in the region of The Four Communes, male, aged 33 to 72 and recorded via censuses). These regional estimates, in turn, will be our dependent variable when we explore the factors associated with the development of numeracy across areas of Western Sudan in the next section.

The regional trends reconstructed from the interaction terms (model in column 3) are reported in Figure 2 for Christians and Figure 3 for Muslims. ${ }^{11}$ The human capital of Christians in Gorée and the Four Communes grew remarkably over the period considered, especially after 1850. The same trend is discernible for Christians whose region of birth could not be determined and, to a lesser extent, the furthest region of Casamance.

The regional trends for Muslims show a quite different, more heterogeneous pattern of human capital development, characterized by large and growing regional inequalities. On average, our figures are slightly more pessimistic than the 60 percent literacy suggested by Sylviane A. Diouf (2013). Previous estimates of 60 percent literacy would have implied a somewhat higher numeracy level of approximately 80-90 percent (A'Hearn, Baten, and Crayen 2009). However, we find that the numeracy

\footnotetext{
${ }^{11}$ We choose this model because it offers the largest number of observations, which covers more regions over time.
} 


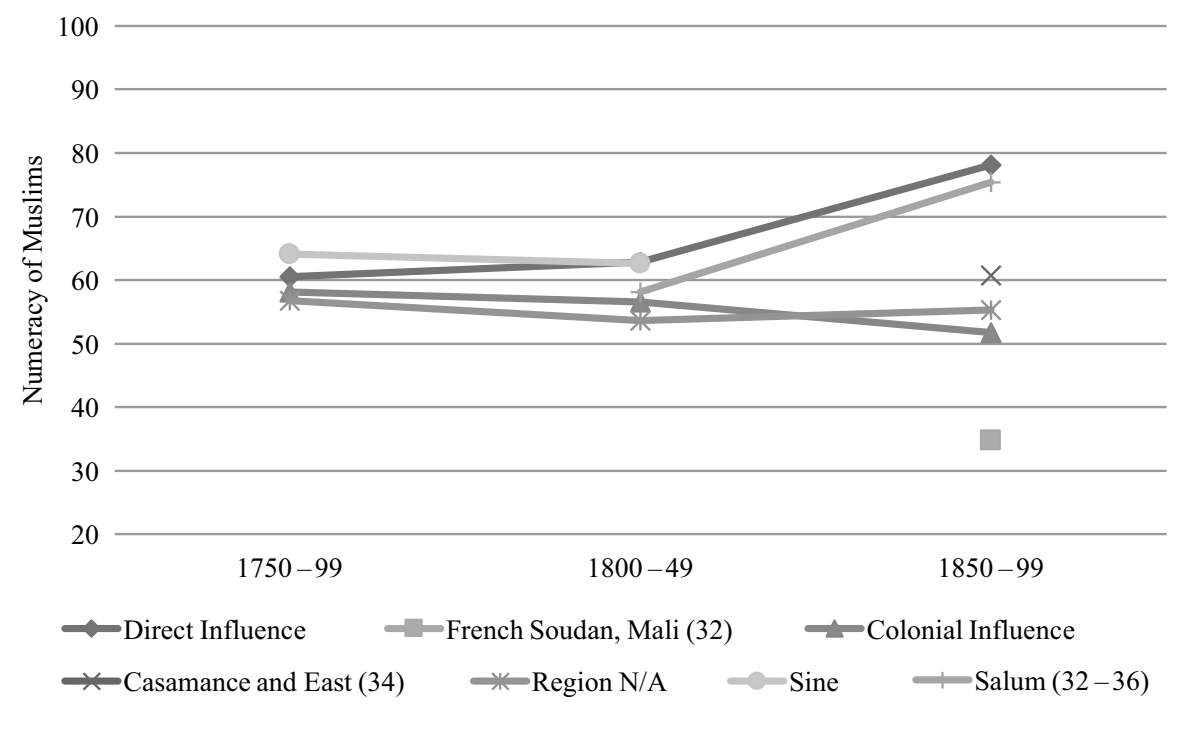

FIGURE 3

THE NUMERACY OF MUSLIMS BY REGION OF SENEGAL, C. 1750-1900

Notes: French Sudan (Mali), Salum, and Casamance and East are based on small samples, as noted in the legend. "Direct influence": see notes to Figure 2.

Sources: See text.

of Muslims in large areas of Western Sudan only approached 60 percent by the mid-nineteenth century. The trend in the Four Communes reflects the human capital of unskilled Christians, although a gap of approximately 10 percentage points in numeracy compared to Muslims persists. The trend in the region of colonial influence, including Cayor, Baol, Jolof, and Futa Toro, shows that the human capital of Africans from Western Sudan declined to 52 percent during the second half of the nineteenth century (or stagnated, as this is probably not statistically significant). The result is similar to the trend for Muslims whose region of birth was unknown. The numeracy of Muslims in the Casamance region was still quite low (61 percent) during the second half of the nineteenth century. However, the human capital of Muslims in Sine-Salum was fairly high (c. 60 percent) during the early nineteenth century and grew considerably after 1850.

Table 3 compares our estimates to those obtained from other countries in sub-Saharan Africa, North Africa, and the Middle East. Mali (Kayes) ranks among the countries with the lowest numeracy, whereas the Four Communes rank among the highest, with the area of colonial influence and Casamance ranking somewhere in between. After discussing potential selectivity concerns in the next section, we outline and explore a number of hypotheses regarding the factors that might have affected this regional pattern of human capital accumulation. 
TABLE 3

COMPARATIVE LEVELS OF NUMERACY IN REGIONS OF SENEGAL AND SUB-SAHARAN AND MIDDLE-EAST COUNTRIES

\begin{tabular}{lc}
\hline \hline Country or Region & Numeracy in 1890 (Percent) \\
\hline Egypt & 16 \\
Morocco & 25 \\
Kuwait & 27 \\
Kayes, Mali (Muslims) & $\mathbf{3 5}$ \\
Iran & 47 \\
Iraq & 47 \\
Senegal - Colonial Influence (Muslims) & $\mathbf{5 2}$ \\
Turkey & 53 \\
Nigeria & 56 \\
Guinea-Bissau & 57 \\
Kenya & 59 \\
Senegal - Casamance and SE (Muslims) & $\mathbf{6 1}$ \\
Tanzania & 64 \\
Togo & 67 \\
Ghana & 70 \\
Liberia & 71 \\
Senegal - Salum (Muslims) & $\mathbf{7 5}$ \\
Tunisia & 76 \\
Senegal - Four Communes (Muslims) & $\mathbf{7 8}$ \\
Algeria & 79 \\
South Africa & 79 \\
Swaziland & 88 \\
Botswana & 89 \\
\hline Source: Our & \\
\hline
\end{tabular}

Source: Our own elaboration from Crayen and Baten (2010).

\section{Potential Sources of Selectivity}

This sub-section discusses a number of factors that could have led to positive or negative selection of the recorded individuals into our historical samples with respect to their underlying population. This issue needs to be addressed when inferring human capital trends from historical samples, which are typically not entirely random.

First, regarding the electoral registers, because the French Colonial Government in Senegal aimed to provide voting rights to the indigenous and métis adult males in the second half of the nineteenth century, positive or negative bias from legal restrictions should not be an issue in principle. ${ }^{12}$ In practice, however, access to electoral registers was likely

\footnotetext{
${ }^{12} \mathrm{We}$ also control for gender-related potential bias in our estimates.
} 
rather limited for the poorer and less educated strata of the population. Therefore, we would expect an upward bias in numeracy for individuals recorded via this source. We attempt to control for this in the regressions with a dummy variable for observations obtained from electoral registers (22 percent of our sample). The bias may or may not be constant, though, and so we perform a robustness test by simply excluding all individuals recorded via this type of source. We find that the results are very similar to the baseline specification that includes all observations (see column 4 of Table 2).

It is also possible that skilled individuals were more likely to migrate to the coastal region of the Four Communes and, as a result, more likely to be included in the Gorée census data. To assess this possibility, we compare the level of numeracy measured in coastal versus interior regions of Senegambia constructed from Gorée's sources with similar measures obtained from records of Senegambian slaves deported to Havana in the early nineteenth century. All slaves arriving to Havana, the trade capital of Latin America in much of the period, were recorded (Eltis 2007). If relative regional values are similar across these two different samples, one can argue that migrant selectivity was probably not strong because selection into slavery was, to a large extent, randomly distributed across Western Sudan. Indeed, considering evidence on the heights of slaves, Eltis has argued strongly that the bias between African slaves brought to the Americas and the populations from which they came was small or even negligible (Eltis 1982, pp. 455-56; see also Austin, Baten, and Van Leeuwen 2012; Baten and Blum 2014). ${ }^{13}$ Figure 4 shows that the numeracy of African slaves who were brought to Havana closely reflects the level of human capital of West African Muslims that we estimate from the Gorée census surveys. We repeat the same selectivity assessment comparing our samples with slaves deported to other world regions, and none of these comparisons suggests strong selectivity, as shown in Table $4 .{ }^{14}$

If there were migrant selectivity, we conjecture that it would be more likely upward than downward, given migration costs. The patterns

${ }^{13}$ For example, Eltis (1982) argues that the hypothesis that African slaves (brought to the Americas) were positively selected from their populations is not correct. The African slaveowners also needed strong workers. Hence, a substantial share of tall and strong slaves were kept in Africa. This is why, according to Eltis, the height distribution of slaves for all regions of embarkation is normal, instead of being skewed to the top. Furthermore, if the demand for slaves was high in regions with taller populations, prices, and volumes of trade there should have been higher-but this was in fact not the case.

${ }^{14}$ One may object that the selectivity concerning migration and slavery could be the same, just because more people tend to be captured as slaves and, likewise, migrate from less cohesive societies (Marfouk 2008 argues that a link between linguistic fractionalization and migrant selectivity does exist in modern-day Africa). However, fractionalization in the context of Senegambia seems very unlikely to have promoted a positive selectivity of slaves (see Appendix B). 


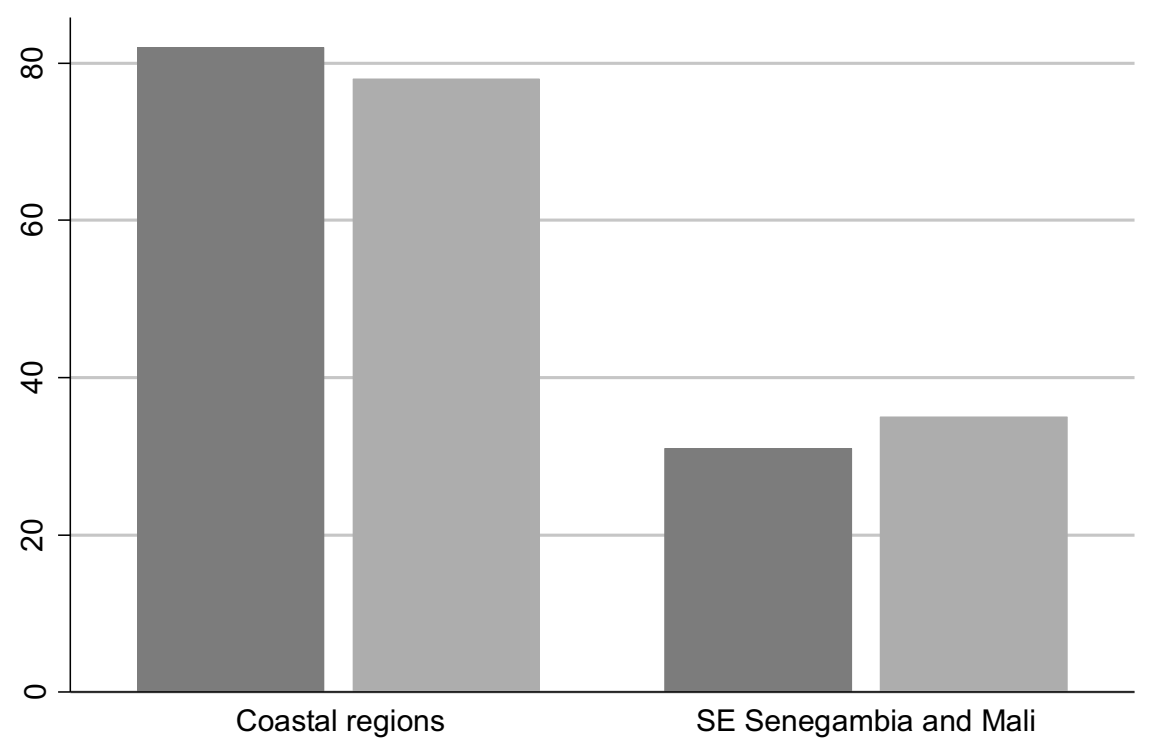

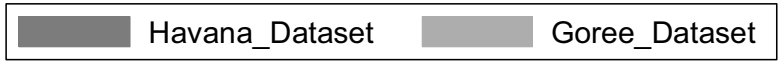

FIGURE 4

AN ASSESSMENT OF POTENTIAL MIGRANT SELECTIVITY THROUGH ESTIMATES OF AFRICANS' NUMERACY (PERCENT) REPORTED IN TWO DIFFERENT SOURCES

Notes: Most of the slaves recorded in the Havana dataset were born during the period 1780-1810, while the Muslim Africans we observe were all born between 1850 and 1900; hence, there is a gap of (on average) 60 to 70 years between the samples. However, note that our estimates of regional trends in numeracy suggest that human capital stagnated in various areas of Western Sudan.

Sources: The "Havana_Dataset" refers to a dataset on the shipment of African slaves to the port of Havana during the early nineteenth century obtained from the Transatlantic Slave Trade Database. Two main categories of individuals are considered: "coast" refers to slaves shipped from the port of Bissau (Portuguese Guinea) and "interior" represents slaves belonging to Mandingo tribes, who inhabited an area that stretched from contemporary southwestern Mali to southeastern Senegal. The "Goree_Dataset" refers to our dataset on Western Sudan. Here, "coast" refers to Muslim individuals born in the coastal cities called the Four Communes, while "interior" refers to a sample of Muslims born in French Sudan, today's Kayes, which is located in Mali.

discussed later focus on the low level and stagnation of numeracy in the interior regions. In the presence of positive migrant selectivity from the interior, the true differences would be even stronger than observed in Gorée census surveys. Thus, while we cannot dismiss migrant selectivity completely, the available evidence suggests that potential bias is not likely to be substantial enough to undermine the basic results.

Finally, we discuss another potential source of bias in the data for slaves (27 percent of our sample). In particular, we are concerned that some of the slaves' age statements might have been declared by their owners. This may positively bias estimates of numeracy because age was declared by Christian owners who might have had the opportunity to 
TABLE 4

NUMERACY IN WESTERN MALI ACCORDING TO DIFFERENT SOURCES

\begin{tabular}{lcccc}
\hline \hline & $\begin{array}{c}\text { Gorée Census } \\
\text { Lists }\end{array}$ & $\begin{array}{c}\text { Slaves Deported } \\
\text { to Havana }\end{array}$ & $\begin{array}{c}\text { Slaves Deported } \\
\text { to Brazil }\end{array}$ & $\begin{array}{c}\text { Slaves Deported to } \\
\text { United States }\end{array}$ \\
\hline Estimated numeracy & 35 & 31 & 31 & 32.5 \\
Observations & $(32)$ & $(418)$ & $(295)$ & $(112)$ \\
\hline
\end{tabular}

Notes: We obtained a numeracy value from the Gorée census list of 35 and compared it in the paper with the numeracy of Mandingo people, who inhabited a region that largely overlapped with that of Kayes, in Western Mali. We obtain estimates of numeracy for the Mandingoes by using lists of slaves deported to Havana, and we find a very similar value to that of Gorée (31). Moreover, we can compare the latter to other slave lists in order to assess the robustness of the estimates. For example, Mandingo slaves deported to Brazil also had a numeracy of 31 and Mandingo slaves deported to the Southern region of the US had a numeracy of 32.5. Although the data from Gorée concern people born several decades later than slaves deported to the Americas, note that the estimated trends for numeracy in the interior regions of Africa highlight stagnation over time (see Figure 3 in the paper). The numeracy calculated from Gorée census lists refers to Muslim Africans born in Western Mali (French Sudan) between 1850 and 1900. The numeracy of slaves deported to Havana, US and Brazil refers to Mandingo people who inhabited the same region, born in 1750-1810 (Havana dataset) and 1770-1780 (Brazil data). The number of observations of each sample is shown is brackets.

Sources: Data from Gorée were collected from the National Archives of Senegal in Dakar. Data on slaves deported to Havana were collected through the Trans-Atlantic Slave Trade Database, see Eltis (2007). The U.S. dataset is based on slave records from Louisiana, collected by MidloHall (Midlo-Hall 2000). Data on slaves deported to Brazil are based on the work of Hawthorne (2010). Both the United States and Brazil data are available online through the project "Slave biographies: Atlantic database network." See http://slavebiographies.org/project/.

examine previously stated ages in other lists and calculate an unrounded age (e.g., if the slaves had been in their households for three years). We control for this in Table 2 by including interaction terms between the dummies that capture religion and those that identify slaves. Indeed, slavery is associated with a positive premium for Muslims, which suggests that slaves did not always declare their ages themselves and that their masters sometimes did so. However, a part of this premium might be due to relatively high numeracy of slaves in Gorée and Dakar. The results remain practically unchanged when we exclude slaves from the sample as an additional robustness check (column 5 of Table 2).

Last but not least, it is possible that Muslim Africans might have avoided cooperation with census takers, not least because of differences in language. However, we find that the numeracy of Muslims in Western Sudan was not extremely low, as we might have expected if all ages were estimated by census personnel due to non-cooperation. For example, it was higher than the numeracy of eighteenth century Muslims and non-Muslims in South Africa, for which there is evidence that each individual was asked for their age (Baten and Fourie 2015). Because of the very mixed character of Gorée's society, we believe that language barriers could be easily overcome. Moreover, there is some consistency 
if we estimate numeracy for the group whose information on religion was unknown to the authorities and compare it to the Muslim Africanslevels and trends were quite similar. This evidence suggests that while non-cooperative behavior might have existed, it is not likely to represent a major obstacle to estimating numeracy. ${ }^{15}$

\section{SECOND-STEP RESULTS: CORRELATES OF NUMERACY ACROSS REGIONS OF WESTERN SUDAN}

This section presents the second step in our analysis: we exploit the variation of numeracy across macro-regions of Western Sudan and over time (values obtained through step 1) to explore the correlation between human capital and the factors outlined in the literature review. We focus on four main explanatory variables: (1) distance from Gorée, (2) the presence of cash crops and its interaction with societal features, (3) slavery, and (4) military activities - including additional controls.

First, as discussed earlier, Inikori (2007) suggests that the rise of the Atlantic slave trade brought about a disintegration of Senegambia's regional market before the early nineteenth century. Coastal areas became more integrated with the Atlantic trade network, while interior suppliers ceased to specialize, reverted to self-subsistence, and abandoned previous trade networks while pillaging increased. We use the distance from Gorée to assess whether exposure to the Atlantic economy and the disintegration of Senegambia's regional market was associated with human capital development. If so, we expect distance to be negatively correlated with numeracy.

Second, we also explore whether the contact with Europeans was related to the regional growth of numeracy after the twilight of the Atlantic slave trade, when the demand for peanuts grew exponentially in the second half of the nineteenth century. As noted earlier, features of West African societies interacted with the rise of peanut as a cash crop. The more stable regions of Sine and Salum, experienced the most remarkable increase in numeracy during the second half of the nineteenth century. Peanut production was likely to benefit a large share of the Serer society for many distinct but related reasons. The Serer used land more intensively than their neighbors did, and exhibited denser patterns of settlement (Curtin 1975, p. 27), which in turn depended on horizontal

\footnotetext{
${ }^{15}$ The people identified as Muslims had, indeed, lower numeracy than the métis or Europeans, but only by a modest amount. The strongest differences could be observed across Muslim groups coming from different regions and birth cohorts, and we will show how these disparities can be explained in the following sections. We can conclude from this that non-cooperative behaviour does not prevent the analysis of these sources.
} 
ties and resistance to encroachment that allowed the development of more stable economic units among the Serer peasantry. This qualitative evidence is consistent with that discussed by Fall (2010), who argues that the rise of peanut production had a positive impact in regions characterized by high population density and domestic peanut production on relatively small farms.

We study how the interaction between the incentives from producing peanuts as a cash crop and societal features affected human capital formation. We code a dummy which is equal to one if the majority of a macroregion's territory was in the so-called peanut basin. Given that the impact of cash crops may have been heterogeneous across macro-regions of Western Sudan, in one specification we also interact this with a dummy equal to one for regions characterized by higher population densities, more equal and stable societies, where slavery was less prominent in the production of groundnuts (namely, Sine and Salum).

A third hypothesis - partly connected to Inikori's idea - is that the intensity of slavery within African societies might have hampered the development of human capital, even beyond slave deportations, since slavery was linked to slave raids and pillaging. We capture this mechanism by including a measure of the share of slaves in each regional sample, the coefficient of which we expect to be negative. Although it is hard to come up with a figure for the intensity of slavery in Senegambia during the nineteenth century, estimates provided by Moitt (1989, pp. 29-30) suggest that between 25 and 40 percent of the population of Cayor was enslaved in 1904. Our share for 1800-1850 (52 percent) is broadly consistent with these figures, as it concerns data from the pre-abolition period.

Fourth and finally, French colonial military campaigns were likely related to the numeracy investment of West African parents. We code a dummy variable that takes value one if there was a military campaign during a certain half-century period and in a certain region of Senegal, Mali, or the Gambia, taking the information from the Historical Atlas of Africa (Ajayi and Crowder 1985). We expect its coefficient to be negative, too.

We use weighted least squares (weights being the number of individuals in each region as a share of the total observations in our sample) to regress regional $\mathrm{ABCC}$ on a number of covariates that could be related to the numeracy differences observed in our sample. Summary statistics are reported in Table 5 (data are available through the Open ICPSR repository, see Cappelli and Baten 2017). Besides the aspects discussed thus far, we include further control variables. A dummy is used to identify areas that were (negatively) affected by jihad and marabout wars. This has been coded by drawing on A Political Chronology of Africa (Lea and Rowe 2001). According to this source, only one major conflict affected 
TABLE 5

SUMMARY STATISTICS FOR WEIGHTED LEAST SQUARES REGRESSION

\begin{tabular}{lccccc}
\hline \hline Variable & $\mathrm{N}$ & Mean & SD & Minimum & Maximum \\
\hline ABCC Value & 25 & 62.66 & 11.01 & 34.75 & 88.45 \\
Distance from Gorée, Km & 25 & 122 & 134 & 11 & 642 \\
Share of slaves (sample) & 25 & 31.44 & 27.24 & 0.00 & 86.00 \\
Share of aged 23-32 (sample) & 25 & 33.72 & 24.20 & 0.00 & 78.00 \\
Base term: peanut area (dummy) & 25 & 0.08 & 0.28 & 0.00 & 1.00 \\
Base term: low-slavery area (dummy) & 25 & 0.28 & 0.46 & 0.00 & 1.00 \\
Military campaign (dummy) & 25 & 0.12 & 0.33 & 0.00 & 1.00 \\
Jihad / African war (dummy) & 25 & 0.12 & 0.33 & 0.00 & 1.00 \\
Distance from Timbuktu, Km (TST) & 25 & 1,480 & 121 & 942 & 1,554 \\
Muslim (dummy) & 25 & 0.48 & 0.51 & 0.00 & 1.00 \\
Religion unknown (dummy) & 25 & 0.36 & 0.49 & 0.00 & 1.00 \\
\hline
\end{tabular}

Sources: See text.

the region of colonial influence in 1750-1800, when the Fulani Kingdom rose to dominance in Futa Toro. However, several jihad wars fueled by marabouts affected the same region between 1850 and 1900 (idem, pp. 358-59)..$^{16}$ Finally, two dummy variables are used to identify regional numeracy calculated from Muslim individuals and from individuals whose religion was unknown, as compared to regional figures based on Christian inhabitants. We expect especially the first one to be negatively correlated with numeracy.

We estimate one specification with pooled data and one with time-fixed effects (i.e., half-centuries of birth as previously defined). In a third specification we include the interaction between areas where peanut production was prominent and regions characterized by better endowments and a limited use of slavery for its production. In a last model, we test whether the distance from Trans-Saharan trade networks (measured as the distance from Timbuktu) played any role in explaining the pattern of regional numeracy that we find..$^{17}$ Although the present analysis should be regarded as exploratory given the small number of observations, we can assess some of the interpretations offered in the previous section. ${ }^{18}$ The

\footnotetext{
${ }^{16}$ The dataset provided by Brecke through the Centre for Global Economic History reports a conflict in the south-east of Senegambia in c. 1810, but we were not able to assess the numeracy of this region for this particular period. See http://www.cgeh.nl/data (accessed on 28 August 2015).

${ }^{17}$ Given the very high correlation between the distance from Gorée and that from Timbuktu ( $\rho$ $=-0.90)$ we include the latter in a separate model.

${ }^{18}$ The small number of observations would imply less statistical significance (unless influential outliers generated spurious results, but we checked carefully that this was not the case. The fact that we observe significant results gives some credibility to our findings).
} 
results should also be taken as correlates rather than definitive evidence of causal relationships.

The econometric results are reported in Table 6. The distance from Gorée confirms the existence of a regional NW-SE gradient in the levels of human capital in Western Sudan. This is consistent with the argument that the incentives brought about by the rise of trade and other interactions with Europeans fostered development in numeracy in coastal regions. According to our fullest models, moving $100 \mathrm{~km}$ further away from Gorée is associated to a reduction of numeracy equal to about 5 percentage points.

When we take into account the passage of time by using half-century dummies, the coefficient of slavery is scaled down, to the point that it becomes small and statistically indistinguishable from zero. This suggests that the correlation between numeracy and slavery is largely the result of a common time trend.

We find that the cultivation of groundnut did not itself guarantee faster human capital accumulation. Only in areas characterized by better endowments and thus high population densities, by more stable and equal societies, and by limited reliance on slavery (like Sine and Salum) did peanut production bring about higher levels of human capital. The coefficient of the interaction term in column 3, equal to 20.5 additional numeracy percentage points, is of substantial magnitude and statistically significant. The presence of a rather equal and cohesive society, characterized by small-scale production and a widespread economic culture (Austin 2016) given the proximity to the Gambia River, interacted with the opportunities provided by peanut exports. This allowed the peasants to accumulate resources to fight back ceddo regimes and promote human capital accumulation in the area, which was also largely untouched by French early colonialism.

The other results are mostly as expected. Having been influenced by French military campaigns is always strongly and negatively correlated with numeracy (but only in one model the result appears to be statistically significant). Consistent with previous estimates, Muslim religion is associated with lower numeracy. The half-century dummies underline a positive trend in numeracy across regions of Western Sudan in the second specification. Finally, we estimate a positive (but not statistically significant) coefficient for the distance from Timbuktu (column 4). While this contrasts with Ghislaine Lydon's hypothesis on the importance of Islam and Trans-Saharan trade for the rise of a commercial culture and literacy in the region (Lydon 2009, p. 353), the religious wars initiated in Western Sudan by Islamic leaders might explain why being more distant from Timbuktu is associated to higher numeracy. This is consistent with 
TABLE 6

CORRELATES OF NUMERACY ACROSS REGIONS OF WESTERN SUDAN, 1770-1890

\begin{tabular}{|c|c|c|c|c|}
\hline Dependent Variable & $\begin{array}{c}(1) \\
\text { Pooled } \\
\text { Numeracy }\end{array}$ & $\begin{array}{c}(2) \\
\text { TFE } \\
\text { Numeracy }\end{array}$ & $\begin{array}{c}\text { (3) } \\
\text { Peanut X LS } \\
\text { Numeracy }\end{array}$ & $\begin{array}{l}\text { (4) } \\
\text { Dist. Timbuktu } \\
\text { Numeracy }\end{array}$ \\
\hline Distance from Goree, $\mathrm{Km}$ & $\begin{array}{c}-0.0231 \\
(0.022)\end{array}$ & $\begin{array}{c}-0.0482 * * * \\
(0.014)\end{array}$ & $\begin{array}{l}-0.0538 * * * \\
(0.013)\end{array}$ & \\
\hline Share of slaves (sample) & $\begin{array}{l}-0.3046^{* * *} \\
(0.079)\end{array}$ & $\begin{array}{l}0.0873 \\
(0.067)\end{array}$ & $\begin{array}{l}0.0332 \\
(0.087)\end{array}$ & $\begin{array}{l}0.0835 \\
(0.101)\end{array}$ \\
\hline Peanut X low-slavery area & & & $\begin{array}{l}20.5139 * * * \\
(4.537)\end{array}$ & \\
\hline $\begin{array}{l}\text { Base term: peanut area } \\
\text { (dummy) }\end{array}$ & $\begin{array}{l}15.7789 \\
(17.104)\end{array}$ & $\begin{array}{c}2.3396 \\
(11.906)\end{array}$ & $\begin{array}{l}-14.2854 \\
(9.010)\end{array}$ & $\begin{array}{l}-7.1714 \\
(25.993)\end{array}$ \\
\hline $\begin{array}{l}\text { Base term: low-slavery area } \\
\text { (dummy) }\end{array}$ & & & $\begin{array}{l}4.4824 \\
(3.637)\end{array}$ & \\
\hline Military campaign (dummy) & $\begin{array}{l}-29.1363 * \\
(13.872)\end{array}$ & $\begin{array}{l}-8.5459 \\
(8.819)\end{array}$ & $\begin{array}{l}-6.3066 \\
(7.868)\end{array}$ & $\begin{array}{l}2.3710 \\
(27.875)\end{array}$ \\
\hline $\begin{array}{l}\text { Jihad / African War } \\
\text { (dummy) }\end{array}$ & $\begin{array}{l}1.9050 \\
(5.644)\end{array}$ & $\begin{array}{l}-0.1127 \\
(3.631)\end{array}$ & $\begin{array}{l}5.3538 \\
(3.248)\end{array}$ & $\begin{array}{l}-1.9913 \\
(3.733)\end{array}$ \\
\hline Muslim (dummy) & $\begin{array}{c}-3.5326 \\
(4.027)\end{array}$ & $\begin{array}{l}-9.4144 * * * \\
(1.696)\end{array}$ & $\begin{array}{c}-9.3380 * * * \\
(1.728)\end{array}$ & $\begin{array}{l}-9.2784 * * * \\
(2.099)\end{array}$ \\
\hline Religion unknown (dummy) & $\begin{array}{l}-11.5175^{*} \\
(6.123)\end{array}$ & $\begin{array}{l}-4.5534 \\
(3.682)\end{array}$ & $\begin{array}{l}-7.4626^{* *} \\
(2.960)\end{array}$ & $\begin{array}{l}-4.0309 \\
(3.792)\end{array}$ \\
\hline Born in $1750-1799$ & & $\begin{array}{l}-28.3866^{* * *} \\
(5.347)\end{array}$ & $\begin{array}{l}-24.6194 * * * \\
(4.839)\end{array}$ & $\begin{array}{l}-27.4453 * * * \\
(7.271)\end{array}$ \\
\hline Born in $1800-1849$ & & $\begin{array}{l}-20.2039 * * * \\
(2.471)\end{array}$ & $\begin{array}{l}-17.4945 * * * \\
(2.710)\end{array}$ & $\begin{array}{l}-20.0301 * * * \\
(3.196)\end{array}$ \\
\hline $\begin{array}{l}\text { Distance from Timbuktu, Km } \\
\text { (TST) }\end{array}$ & & & & $\begin{array}{l}0.0666 \\
(0.044)\end{array}$ \\
\hline Constant & $\begin{array}{l}79.9142 * * * \\
(8.168)\end{array}$ & $\begin{array}{l}81.5766^{* * *} \\
\quad(5.099)\end{array}$ & $\begin{array}{l}82.9394 * * * \\
\quad(4.271)\end{array}$ & $\begin{array}{r}-23.6825 \\
(64.404)\end{array}$ \\
\hline Observations & 25 & 25 & 25 & 25 \\
\hline Adjusted R-squared & 0.682 & 0.913 & 0.946 & 0.867 \\
\hline
\end{tabular}

Robust standard errors in parentheses.

$* * * \mathrm{p}<0.01, * * \mathrm{p}<0.05, * \mathrm{p}<0.1$

Notes: The distance from Gorée refers is calculated by referring to: (1) Dakar for the area of direct French rule, i.e., the Four Communes; (2) Banjul (formerly Bathurst) for British Gambia; (3) Ziguinchor for Casamance; (4) Fatick for Sine; (5) Kaolack for Salum; (6) Kayes for French Sudan (Mali); finally, given the extension of the area of colonial influence, we calculate an unweighted average of the distance between Gorée and Diourbel (Baol) and Gorée and Mboul (Cayor). We also control for the share of females in the sample. We exclude region fixed effects because they are likely to capture the entire source of variation in the data, given that our independent variables are mostly time-invariant and coded as dummies, and that we can extract only 25 observations for regional $\mathrm{ABCC}$ values. The share of young adults (23-32) is included to capture a potential remaining numeracy premium associated with youth.

${ }^{\text {a }}$ In column 3, we include the dummy that identifies low-slavery areas, characterized by higher population densities and more stable and equal societies than inner regions, and its interaction with areas characterized by peanut production.

Sources: See text. 
previous findings by Valeria Prayon (2013), who identified a negative cross-country relationship between Islam and numeracy.

\section{CONCLUSIONS}

Research on the economic history of Africa has uncovered important links connecting colonialism and development (Frankema 2012; Jerven et al. 2012; Cogneau and Moradi 2014; Cappelli and Baten 2016; Meier $\mathrm{Zu}$ Selhausen and Weisdorf 2016; Haas and Frankema 2016; Jedwab and Moradi 2016). Yet, the role played by African people and by local conditions as factors that interacted with colonialism and ultimately determined its outcome has been under-researched, failing to build narratives that include African agency as part of the history of the continent's development (Frankema, Green, and Hillbom 2016).

By applying the age-heaping technique to pre-colonial and colonial West African sources, we obtain the first estimates of human capital trends across regions of Western Sudan from the late-eighteenth century to 1900. This approach allows us to overcome crucial data issues in order to move beyond a "compressed" economic history of Africa. By relying on new quantitative evidence, we shed light on the development of this important world region (Fourie 2016). In particular, we argue that the connection between European trade, early colonialism, and human capital development was heterogeneous across regions of West Africa between 1770 and 1900 .

The growing regional disparities in human capital accumulation that we observe are consistent with the hypothesis originally put forward by Inikori (2007). He argued that the slave trade brought about a disintegration of regional markets within West Africa. Coastal areas linked to the slave trade developed more than other regions, which were affected negatively by pillaging and slave raids. Indeed, we find that the inhabitants of the Four Communes, on the coast of present-day Senegal, possessed relatively high numeracy, which increased throughout the nineteenth century. We also identified a persistent gap between Christians (mainly Franco-African Creoles and a tiny minority of Europeans) and Muslims within this area. By contrast, the regional development of numeracy in the interior was more heterogeneous, so that we expand Inikori's hypothesis by taking into account a number of additional factors that were likely to affect human capital accumulation.

One of them was the growth of peanut production and trade in the second half of the nineteenth century, following the abolition of slavery. Within the inner region of central and northern Senegal - characterized by poor endowments, low population densities, and very hierarchical 
societies who made large use of slaves - human capital stagnated or even declined throughout the nineteenth century. Instead, Muslim individuals born in the regions of Sine and Salum - more equal, stable, and less reliant on slavery - embarked on a path of rather sustained human capital accumulation during the growth of peanut trade. This human-capital regional divide was further reinforced by French colonial campaigns, beginning in the mid-nineteenth century, which affected mostly the northwestern regions of Senegambia at that time. This clear pattern helps us to understand why the evaluation of the economic impact of colonialism should be investigated, when possible, across regions of Africa, even within the same present-day countries (Frankema, Green, and Hillbom 2016).

In sum, although European influence and French colonial policy were important factors for the development of Western Sudan before 1900, the cultural and socioeconomic features that characterized different African kingdoms and societies were equally relevant in shaping its fortune. Regions specialized in advanced agricultural technology and based on less hierarchical social structures were characterized by a positive trend in human capital. This demonstrates that African agency was central to the development of the region and interacted with the opportunities and constraints provided by the French colonial occupation towards the end of the nineteenth century.

\section{Appendix A}

APPENDIX TABLE 1

POPULATION IN SENEGAL'S REGIONS, C. 1891

\begin{tabular}{lccc}
\hline \hline $\begin{array}{l}\text { Pre-colonial Kingdoms and } \\
\text { Regions 1750-1900 }\end{array}$ & Population & $\begin{array}{c}\text { Regions Recoded } \\
1750-1900\end{array}$ & Population \\
\hline Four Communes, 1882 & 63,861 & Direct Influence, 1882 & 63,861 \\
Sine, 1891 & 52,233 & Sine, 1891 & 52,233 \\
Saloum, 1891-1892 & 58,310 & Saloum, 1891-1892 & 58,310 \\
Baol, 1891 & 151,197 & - & \\
Kayor, 1896 & 95,096 & - & \\
Walo, 1896 & 32,140 & - & \\
Jolof, 1895 & 15,605 & - & 543,057 \\
Futa Toro, 1896 & 249,019 & Colonial Influence, c. 1890 & \\
Boundou, 1896 & 14,108 & - & 201,184 \\
Casamance, 1891 & 187,076 & Casamance \& East & 918,645 \\
Total Senegal c.1891 & 918,645 & Total Senegal c.1891 & \\
\hline
\end{tabular}

Note: the estimates are highly tentative, and should be interpreted with due cautiousness.

Source: Figures are drawn from archival research carried out by Becker et al. (1983). 
APPENDIX TABLE 2

DISTRIBUTION OF OBSERVATIONS ACROSS REGIONS, PERIODS OF BIRTH, AND RELIGIONS

\begin{tabular}{|c|c|c|c|}
\hline \multirow[b]{2}{*}{ Region and Religion } & \multicolumn{3}{|c|}{ Period of Birth } \\
\hline & $1750-1799$ & $1800-1849$ & 1850-1899 \\
\hline \multicolumn{4}{|l|}{ Christians } \\
\hline Mali (Kayes) & & 1 & 4 \\
\hline Direct influence & 108 & 640 & 591 \\
\hline France and offshoots & 2 & 9 & 43 \\
\hline French Antilles & 2 & 2 & \\
\hline Gambia (UK) & 11 & 40 & 33 \\
\hline Guineas & & 9 & 33 \\
\hline Colonial influence & 26 & 20 & 6 \\
\hline SW Africa & & 2 & 12 \\
\hline Sine-Salum & 18 & 40 & 38 \\
\hline South-East & & 14 & 79 \\
\hline N/A & 171 & 484 & 106 \\
\hline \multicolumn{4}{|l|}{ Muslims } \\
\hline Mali (Kayes) & 1 & 5 & 41 \\
\hline Direct influence & 56 & 466 & 435 \\
\hline France and offshoots & 3 & 8 & 4 \\
\hline French Antilles & 1 & 13 & \\
\hline Gambia (UK) & 17 & 22 & 23 \\
\hline Guineas & 1 & 5 & 11 \\
\hline Indirect influence & 99 & 165 & 51 \\
\hline SW Africa & 1 & 2 & 2 \\
\hline Sine-Salum & 68 & 82 & 44 \\
\hline South-East & 8 & 31 & 41 \\
\hline N/A & 371 & 684 & 50 \\
\hline \multicolumn{4}{|l|}{ Religion unknown } \\
\hline Mali (Kayes) & & & 9 \\
\hline Direct influence & 166 & 810 & 896 \\
\hline France and offshoots & 2 & 10 & 48 \\
\hline French Antilles & & 24 & \\
\hline Gambia (UK) & 12 & 72 & 18 \\
\hline Guineas & & 24 & 9 \\
\hline Colonial influence & 100 & 180 & 10 \\
\hline SW Africa & 2 & 8 & 45 \\
\hline Sine-Salum & 63 & 106 & 29 \\
\hline South-East & 13 & 32 & 40 \\
\hline N/A & 301 & 1,579 & 1,408 \\
\hline
\end{tabular}

Source: See text. 


\section{Appendix B}

Note on Footnote 14: One may object that the selectivity concerning migration and slavery could be the same, just because more people tend to be captured as slaves and, likewise, migrate from less cohesive societies (Marfouk 2008 argues that a link between linguistic fractionalization and migrant selectivity does exist in modern-day Africa). However, fractionalization in the context of Senegambia seems very unlikely to have promoted a positive selectivity of slaves. In the very hierarchical society of the Wolof, where slave raids were more common than in other societies, those who captured slaves were also likely to be the ones better off. Therefore, slaves likely were a negatively selected sample relative to their populations of origin, not a positive selection; yet, the fact that the buyers' demand was also taken into account might actually balance out the former effect (i.e., no weak slaves), which might explain why Eltis does not find a strong selectivity in the first place, and the distribution of slaves relative to their regions of origin looks normal.

\section{REFERENCES}

A'Hearn, Brian, Joerg Baten, and Dorothee Crayen. "Quantifying Quantitative Literacy: Age Heaping and the History of Human Capital.” Journal of Economic History 69, no. 3 (2009): 783-808.

Ajayi, Jacob Festus Ade, and Michael Crowder. Historical Atlas of Africa. Cambridge: Cambridge University Press, 1985.

Allen, Robert C. Global Economic History: A Very Short Introduction. Oxford: Oxford University Press, 2011.

Armstrong, Alan. Stability and Change in an English Country Town. A Social Study of York 1801-1851. London: Cambridge University Press, 1974.

Atmore, Anthony E., Oliver Roland, and George N. Sanderson. "Africa on the Eve of Partition." In The Cambridge History of Africa., Vol. 6. From 1870 to 1905. Cambridge: Cambridge University Press, 1985.

Austin, Gareth. "Resources, Techniques, and Strategies South of the Sahara: Revising the Factor Endowments Perspective on African Economic Development, 1500 20001." Economic History Review 61, no. 3 (2008a): 587-624.

- "The 'Reversal of Fortune' Thesis and the Compression of History: Perspectives from African and Comparative Economic History." Journal of International Development 20, no. 8 (2008b): 996-1027.

- "African Economic Development and Colonial Legacies." International Development Policy | Revue Internationale de Politique de Développement, no. 1 (2010): 11-32.

-. "Subsaharan Africa, 1500-2000." In A History of the Global Economy: 1500 to the Present, edited by Joerg Baten. Cambridge: Cambridge University Press, 2016.

Austin, Gareth, Joerg Baten, and Bas Van Leeuwen. "The Biological Standard of Living in Early Nineteenth-Century West Africa: New Anthropometric Evidence for Northern Ghana and Burkina Faso1.” Economic History Review 65, no. 4 (2012): $1280-302$. 
Barry, Boubacar. Senegambia and the Atlantic Slave Trade. Cambridge: Cambridge University Press, 1998.

Baten, Joerg, ed. A History of the Global Economy. Cambridge: Cambridge University Press, 2016.

Baten, Joerg, and Matthias Blum. "Why Are You Tall While Others Are Short? Agricultural Production and Other Proximate Determinants of Global Heights." European Review of Economic History 18, no. 2 (2014): 144-65.

Baten, Joerg, and Johan Fourie. "Numeracy of Africans, Asians, and Europeans during the Early Modern Period: New Evidence from Cape Colony Court Registers." Economic History Review 68, no. 2 (2015): 632-56.

Baten, Joerg, and Jan Luiten van Zanden. "Book Production and the Onset of Modern Economic Growth.” Journal of Economic Growth 13, no. 3 (2008): 217-35.

Becker, Charles, Victor Martin, Jean Schmitz, et al. "Les premiers recensements au Sénégal et l'évolution démographique. Présentation de documents." Dakar, ORSTOM, Centre IRD de Bondy, 1983.

Bowman, Joye L. "'Legitimate Commerce' and Peanut Production in Portuguese Guinea, 1840s-1880s." Journal of African History 28, no. 1 (1987): 87-106.

Brooks, George E. "Peanuts and Colonialism: Consequences of the Commercialization of Peanuts in West Africa, 1830-70." Journal of African History 16, no. 1 (1975): 29-54.

Cappelli, Gabriele, and Joerg Baten. "The Evolution of Human Capital in Africa, 1730-1970: A Colonial Legacy?” CEPR Discussion Paper No. 11273, Centre for Economic Policy Research, London, 2016.

Cappelli Gabriele, and Joerg Baten. "European Trade, Colonialism, and Human Capital Accumulation in Senegal, Gambia and Western Mali, 1770-1900 [data set]." Ann Arbor, MI: Inter-university Consortium for Political and Social Research [distributor], 2017, http://doi.org/10.3886/E100714V1.

Cogneau, Denis, and Alexander Moradi. "Borders That Divide: Education and Religion in Ghana and Togo Since Colonial Times." Journal of Economic History 74, no. 3 (2014): 694-729.

Crayen, Dorothee, and Joerg Baten. "Global Trends in Numeracy 1820-1949 and Its Implications for Long-Term Growth." Explorations in Economic History 47, no. 1 (2010): 82-99.

Curtin, Philip D. Economic Change in Precolonial Africa: Senegambia in the Era of the Slave Trade. Madison, WI: University of Wisconsin Press, 1975.

Diouf, Sylviane A. Servants of Allah: African Muslims Enslaved in the Americas, 15th Anniversary Edition. New York City: New York University Press, 2013.

Eltis, David. "Nutritional Trends in Africa and the Americas: Heights of Africans, 1819-1839." Journal of Interdisciplinary History 12, no. 3 (1982): 453-75.

—. "A Brief Overview of the Trans-Atlantic Slave Trade." Atlanta, GA: Emory University, 2007.

Fall, Babacar. Sénégal: Le Travail Au XXè Siècle. PhD Thesis, 2010.

Fourie, Johan. "The Data Revolution in African Economic History." Journal of Interdisciplinary History 47, no. 2 (2016): 193-212.

Frankema, Ewout. "The Origins of Formal Education in Sub-Saharan Africa: Was British Rule More Benign?” European Review of Economic History 16, no. 4 (2012): 335-55. 
Frankema, Ewout, Erik Green, and Ellen Hillbom. "Endogenous Processes of Colonial Settlement. The Success and Failure of European Settler Farming in Sub-Saharan Africa." Revista de Historia Economica - Journal of Iberian and Latin American Economic History 34, no. 2 (2016): 237-65.

Getz, Trevor R. Slavery and Reform in West Africa: Toward Emancipation in NineteenthCentury Senegal and the Gold Coast. Athens, OH: Ohio University Press, 2004.

Haas, Michiel de, and Ewout Frankema. "Tracing the Uneven Diffusion of Missionary Education in Colonial Uganda: European Influences, African Realities and the Pitfalls of Church Record Data." African Economic History Network Working Paper Series No. 25, Riksbankens Jubileumsfond, Sweden, 2016.

Hanushek, Eric A., and Ludger Woessmann. "Do Better Schools Lead to More Growth? Cognitive Skills, Economic Outcomes, and Causation." Journal of Economic Growth 17, no. 4 (2012): 267-321.

Hawthorne, Walter. From Africa to Brazil: Culture, Identity, and an Atlantic Slave Trade, 1600-1830. Cambridge: Cambridge University Press, 2010.

Idowu, H. Oludare. "Assimilation in $19^{\text {th }}$ Century Senegal." Cahiers d'études africaines 9, no. 34 (1969): 194-218.

Inikori, Joseph E. "Africa and the Globalization Process: Western Africa, 1450-1850." Journal of Global History 2, no. 1 (2007): 63-86.

Jedwab, Rémi, and Alexander Moradi. "The Permanent Effects of Transportation Revolutions in Poor Countries: Evidence from Africa." Review of Economics and Statistics 98, no. 2 (2016): 268-84.

Jerven, Morten. Africa: Why Economists Get It Wrong. London: Zed Books, 2015.

Jerven, Morten, Gareth Austin, Erik Green, et al. "Moving Forward in African Economic History: Bridging the Gap Between Methods and Sources." African Economic History Network Working Paper Series No. 1, Riksbankens Jubileumsfond, Sweden, 2012.

Klein, Martin A. Islam and Imperialism in Senegal: Sine-Saloum, 1847-1914. Standford,CA: Hoover Institution, Stanford University Press, 1968.

Knight-Baylac, Marie-Hélène. "La vie à Gorée de 1677 à 1789." Revue française d'histoire d'outre-mer 57, no. 209 (1970): 377-420.

—. "Gorée au XVIIIe siècle du sol." Revue française d'histoire d'outre-mer 64, no. 234 (1977): 33-54.

Lea, David, and Annamarie Rowe. A Political Chronology of Africa. London: Taylor \& Francis, 2001.

Leeuwen, Marco H. D. van, and Ineke Maas. Hisclass: A Historical International Social Class Scheme. Leuven, Belgium: Universitaire Pers Leuven, 2011.

Lydon, Ghislaine. On Trans-Saharan Trails: Islamic Law, Trade Networks, and CrossCultural Exchange in Nineteenth-Century Western Africa. Cambridge: Cambridge University Press, 2009.

Marfouk, Abdeslam. "The African Brain Drain: Scope and Determinants." DULBEA Working Paper 08-07.RS, Universite Libre de Bruxelles, 2008.

Meier Zu Selhausen, Felix, and Jacob Weisdorf. “A Colonial Legacy of African Gender Inequality? Evidence from Christian Kampala, 1895-2011.” Economic History Review 69, no. 1 (2016): 229-57.

Midlo-Hall, Gwendolyn. The African Diaspora in the Americas: Regions, Ethnicities, and Cultures. Chapel Hill: University of North Carolina Press, 2001. 
Moitt, Bernard. "Slavery and Emancipation in Senegal's Peanut Basin: The Nineteenth and Twentieth Centuries." International Journal of African Historical Studies 22, no. 1 (1989): 27-50.

Prayon, Valeria. "Contributions to the Discussion on the Determinants of Long-Term Human Capital Development in Today's Developing Regions.” PhD Thesis, University of Tuebingen, 2013.

Richardson, David. "Slave Exports from West and West-Central Africa, 1700-1810: New Estimates of Volume and Distribution." Journal of African History 30, no. 1 (1989): 1-22.

Robinson, David. Paths of Accommodation: Muslim Societies and French Colonial Authorities in Senegal and Mauritania, 1880-1920. Athens, OH: Ohio University Press, 2000.

Rönnbäck, Klas. "The Transatlantic Slave Trade and Social Stratification on the Gold Coast." Economic History of Developing Regions 30, no. 2 (2015): 157-81.

Rousseau, Robert. "La population du Sénégal en 1926." Annales de Géographie 38, no. 214 (1929): 399-403.

Salau, Mohammed Bashir. "The Role of Slave Labour in Groundnut Production in Early Colonial Kano." Journal of African History 51, no. 2 (2010): 147-65.

Searing, James F. West African Slavery and Atlantic Commerce: The Senegal River Valley, 1700-1860. Cambridge: Cambridge University Press, 1993.

Shryock, Henry S., and Jacob S. Siegel, eds. The Methods and Materials of Demography. New York: Academic Press, 1976.

Temple, Jonathan, and Hans-Joachim Voth. "Human Capital, Equipment Investment, and Industrialization.” European Economic Review 42, no. 7 (1998): 1343-62. 